\title{
PENDIDIKAN KEWIRAUSAHAAN DI PONDOK PESANTREN SIDOGIRI PASURUAN
}

\author{
Chusnul Chotimah \\ Sekolab Tinggi Agama Islam Negeri Tulungagung \\ chusnultata@gmail.com
}

\begin{abstract}
This research discuss the entrepreneurship models and its teaching strategy in Sidogiri Islamic boarding school Pasuruan through qualitative method. The finding shows that (1) entrepreneurship values are integrated as religious activities in which any economic activities is part it and intended for God; (2) under the control of boarding school head, the education proses on entrepreneurship is giving the student attempt to organized economic sector in the boarding school.
\end{abstract}

Keywords: Education, entrepreneurship, Islamic boarding school.

\begin{abstract}
Abstrak
Penelitian ini mengkaji model pendidikan kewirausabaan dan strategi pengajarannya di pondok pesantren Sidogiri Pasuruan. Penelitian ini termasuk jenis penelitian lapangan (field research) dengan pendekatan kualitatif, yaitu penelitian yang tidak mengadakan penghitungan data secara kuantitatif, dengan paradigma naturalistik atau interpretif. Data dikumpulkan dari latar yang alami (natural setting) sebagai sumber data langsung. Temuan penelitian ini adalab: (1) Nilai-nilai kewirausahaan yang diinternalisasikan di pondok pesantren Sidogiri adalab nilai kewirausabaan yang berbasis ibadah, dimana segala kegiatan ekonomi yang dilakukan diniatkan untuk beribadab kepada Allah SWT; (2) Proses pendidikan kewirausabaan yang dilaksanakan dengan stategi santri dilatib untuk mengelola lembaga ekonomi yang ada di pondok pesantren di bawah pantauan dan bimbingan dari kiai dan pengurus pondok pesantren.
\end{abstract}

Kata kunci: Pendidikan, kewirausahaan, pondok pesantren 


\section{Pendahuluan}

Pesantren merupakan lembaga pendidikan Islam pertama di Indonesia yang ada dan mendukung kelangsungan sistem pendidikan nasional. Selama ini tidak diragukan lagi kontribusinya dalam rangka mencerdaskan kehidupan bangsa sekaligus mencetak kader-kader intelektual yang siap untuk mengapresiasikan potensi keilmuannya di masyarakat (Tolkhah dan Barizi, 2004: 49). Hal tersebut terbukti dengan munculnya para tokoh pemimpin yang berkaliber Nasional maupun Internasional yang lahir dari pesantren.

Pondok pesantren merupakan salah satu jenis pendidikan Islam di Indonesia yang bersifat tradisional dan berciri khusus, baik sistem pendidikan, sistem belajar maupun tujuan serta fungsinya. Saat ini jumlah pesantren di Indonesia tidak kurang dari 7.000 buah dengan jumlah santri sekitar 11 juta orang dan jumlah tenaga pendidik sekitar 150 ribu orang (Hariadi, 2008: 92). Jumlah tersebut sangat strategis dan menguntungkan bagi pembangunan bangsa Indonesia, terutama dalam era globalisasi, dengan catatan jika potensi ini dapat diberdayakan secara maksimal.

Pondok pesantren, sebagai lembaga pendidikan Islam tertua adalah suatu model pendidikan yang sama tuanya dengan Islam di Indonesia (Sunyoto, 1995: 65), yang didirikan oleh para ulama tempo dulu, ratusan tahun yang silam, hingga saat ini masih bertahan bahkan terus berkembang. Ketahanan pondok pesantren, menurut Abdurrahman Wahid disebabkan pola kehidupannya yang unik (Wahid, 1995: 32), menurut Sumarsono Mestoko, hal ini disebabkan telah melembaganya pesantren di dalam masyarakat (Mestoko, 1986: 232). Sedangkan Azyumardi Azra menilai ketahanan pesantren disebabkan oleh kultur Jawa yang mampu menyerap kebudayaan luar melalui suatu proses internalisasi tanpa kehilangan identitasnya (Azra, 1985: 173), Aya Sofia mengklaim bahwa ketahanan pondok pesantren disebabkan jiwa dan semangat kewiraswastaan yang tinggi (Sofia, et.al., Pedoman Penyelenggaraan Pusat Informasi Pesantren, (1985/1986: 41). Hasan Langgulung mengamati ketahanan pesantren sebagai akibat dari pribadi-pribadi kiai yang menonjol dengan ilmu dan visinya (Langgulung, 1988: 75). Ketahanan yang disebabkan oleh dominannya faktor internal ini, terdapat 
mampu memberikan konstribusi terhadap ketahanan pesantren. Hal ini menunjukkan bahwa terdapat hubungan dan komunikasi yang terjalin baik antara pondok pesantren dengan masyarakat. Artinya, tidak bisa dipungkiri bahwa, keberadaan pondok pesantren menjadi bagian dari sistem kehidupan umat Islam sekaligus penyangga budaya masyarakat Islam dan bangsa Indonesia terutama pada masa penjajahan (Noor, 2006: 2), sehingga pondok pesantren tidak hanya dituntut untuk mengurusi pendidikan agama atau pembelajaran agama Islam, namun juga menanamkan nilai-nilai di masyarakat dan merupakan bagian dari realitas masyarakat yang harus menjalin hubungan yang baik dengan masyarakat dari berbagai sisi.

Berpijak dari pendapat Aria Sofiya di atas, bahwa ketahanan pondok pesantren disebabkan karena jiwa dan semangat kewiraswastaan yang tinggi, maka cukup banyak pondok pesantren yang mengajarkan life skill atau kewirausahaan kepada santrinya sebagai bekal santrinya ketika terjun ke dalam masyarakat. Fenomena ini nampaknya terdapat di salah satu pondok pesantren di Jawa Timur yaitu pondok pesantren Sidogiri. Pondok pesantren tersebut merupakan salah satu pondok pesantren salafiyah yang mempunyai lembaga ekonomi yang cukup banyak. Hal tersebut dikarenakan telah ditanamkan jiwa kewirausahaan di pondok pesantren tersebut. Hal ini sesuai dengan ungkapan yang dikemukakan oleh Saifullah Naji, dalam hal penguatan ekonomi seperti: berkembangnya BMT di 140 cabang di seluruh Indonesia, pendistribusian air minum dengan merek santri, kopontren dengan manajemen modern yang tersebar mencapai 120 cabang di Indonesia, pengolahan limbah sampah, pelatihan maupun diklat kewirausahaan(enterpreneurship) yang sudah terencana, dan lain sebagainya (Naji, Wawancara: 2011).

Berpijak dari hal-hal di atas, dapat dikemukakan bahwa pendidikan kewirausahaan telah mengakar kuat di pondok pesantren Sidogiri, bahkan sampai bisa diwariskan. Maka dari itu, penelitian ini akan mengungkap mengenai pendidikan kewirausahaan di pondok pesantren Sidogiri yang dimulai dari internalisasi nilai-nilai kewirausahaan kemudian dilanjutkan dengan proses pendidikan kewirausahaan di pondok pesantren Sidogiri. 


\section{Kewirausahaan}

Kewirausahaan merujuk pada sifat, watak dan ciri-ciri yang melekat pada individu yang mempunyai kemauan keras untuk mewujudkan dan mengembangkan gagasan kreatif dan inovatif yang dimiliki ke dalam kegiatan yang bernilai. Jiwa dan sikap kewirausahaan tidak hanya dimiliki oleh usahawan, melainkan pula setiap orang yang berpikir kreatif dan bertindak inovatif. Kewirausahaan adalah kemampuan kreatif dan inovatif yang dijadikan dasar, kiat dan sumber daya untuk mencari dan memanfaatkan peluang menuju sukses.

Istilah wirausaha berasal dari kata entrepreneur (bahasa Francis) yang diterjemahkan ke dalam bahasa Inggris dengan arti between taker atau go-between (Depdiknas, 2007: 9). Menurut Suparman Sumohamijaya, sebagaimana dikutip Aris Munandar, istilah wirausaha sama dengan istilah wiraswasta. Wiraswasta berarti keberanian, keutamaan dan keperkasaan dalam memenuhi kebutuhan serta memecahkan permasalahan hidup dengan kekuatan yang ada pada diri sendiri (Munandar, 2006).

Menurut Raymond yang dikutip oleh Tim Dosen Administrasi Pendidikan UPI berpendapat bahwa entrepreneurship atau kewirausahaan merupakan proses penciptaan sesuatu yang baru atau inovasi guna memperoleh kesejahteraan atau kekayaan individu dan mendapatkan nilai tambah bagi masyarakat (Tim Dosen UPI,2009: 354). Kesejahteraan atau nilai tambah dari masyarakat sebagai tujuan dari kewirausahaan itu, dilakukan melalui pengungkapan gagasan baru, penggalian sumber daya, dan merealisasikan gagasan itu menjadi suatu kenyataan yang menguntungkan.

Dengan demikian, wirausaha dalam konteks pondok pesantren adalah seorang pembuat keputusan yang membantu terbentuknya sistem kegiatan suatu lembaga yang bebas dari keterikatan lembaga lain. Sebagian besar pendorong perubahan, inovasi dan kemajuan dinamika kegiatan di pesantren akan datang dari kiai yang memiliki jiwa wirausaha. Wirausaha adalah orang yang mempunyai tenaga dan keinginan untuk terlibat dalam petualangan inovatif. Wirausaha juga memiliki kemauan menerima tanggung jawab pribadi dalam mewujudkan keinginan yang dipilih. 
Seorang wirausaha memiliki daya inovasi yang tinggi, dimana dalam proses inovasinya menunjukkan cara-cara baru yang lebih baik dalam mengerjakan pekerjaan. Dalam kaitannya dengan tugas kiai, kebanyakan di antaranya tidak menyadari keragaman dan keluasan bidang yang menentukan tindakannya guna memajukan pesantren. Mencapai kesempurnaan dalam melakukan rencana merupakan sesuatu yang ideal dalam mengejar tujuan, tetapi bukan merupakan sasaran yang realistik bagi kebanyakan kepala sekolah yang berjiwa wirausaha. Bagi kiai yang realistik hasil yang dapat diterima lebih penting daripada hasil yang sempurna. Setiap orang termasuk kiai yang kreatif dan inovatif adalah individu yang unik dan spesifik.

Kiai yang memiliki jiwa wirausaha pada umumnya mempunyai tujuan dan pengharapan tertentu yang dijabarkan dalam visi, misi, tujuan dan rencana strategis yang realistik. Realistik berarti tujuan disesuaikan dengan sumber daya pendukung yang dimiliki. Semakin jelas tujuan yang ditetapkan semakin besar peluang untuk dapat meraihnya. Dengan demikian, kiai yang berjiwa wirausaha harus memiliki tujuan yang jelas dan terukur dalam mengembangkan pesantrennya. Untuk mengetahui apakah tujuan tersebut dapat dicapai maka visi, misi, tujuan dan sasarannya dikembangkan ke dalam indikator yang lebih terinci dan terukur untuk masing-masing aspek atau dimensi. Dari indikator tersebut juga dapat dikembangkan menjadi program dan sub-program yang lebih memudahkan implementasinya dalam pengembangan pondok pesantren.

Menjadi wirausahawan berarti memiliki kemauan dan kemampuan menemukan dan mengevaluasi peluang, mengumpulkan sumber daya yang diperlukan dan bertindak untuk memperoleh keuntungan dari peluang itu. Mereka berani mengambil risiko yang telah diperhitungkan dan menyukai tantangan dengan risiko moderat. Wirausahawan percaya dan teguh pada dirinya dan kemampuannya mengambil keputusan yang tepat. Kemampuan mengambil keputusan inilah yang merupakan ciri khas dari wirausahawan.

Pada kenyataanya, definisi kewirausahaan mengalami perubahan sesuai dengan periode zaman, artinya tidak ada definisi yang definitif tentang kewirausahaan. Ada yang menyatakan bahwa, 
kewirausahaan adalah mencari dan mempromosikan dari gabungan faktor-faktor produksi yang baru, dan ada pula yang mengatakan bahwa kewirausahaan merupakan pengurangan dari organisasi yang tidak efisien atau merupakan kegiatan untuk mengidentifikasi peluang pasar sehingga kewirausahaan merupakan bangunan organisasi baru.

Jiwa, sikap dan perilaku kewirausahaan memiliki ciri-ciri yakni: (1) penuh percaya diri, dengan indikator penuh keyakinan, optimis, disiplin, berkomitmen dan bertanggungjawab; (2) memiliki inisiatif, dengan indikator penuh energi, cekatan dalam bertindak dan aktif; (3) memiliki motif berprestasi dengan indikator berorientasi pada hasil dan berwawasan ke depan; (4) memiliki jiwa kepemimpinan dengan indikator berani tampil beda, dapat dipercaya dan tangguh dalam bertindak; dan (5) berani mengambil risiko dengan penuh perhitungan.

Aksioma yang mendasari proses kewirausahaan adalah adanya tantangan untuk berpikir kreatif dan bertindak inovatif sehingga tantangan teratasi dan terpecahkan. Ide kreatif dan inovatif wirausaha tidak sedikit yang diawali dengan proses imitasi dan duplikasi, kemudian berkembang menjadi proses pengembangan dan berujung pada proses penciptaan sesuatu yang baru, berbeda dan bermakna. Tahap penciptaan sesuatu yang baru, berbeda dan bermakna inilah yang disebut tahap kewirausahaan.

Menurut Hakim, ada empat unsur yang membentuk pola dasar kewirausahaan yang benar dan luhur, yaitu: (1) sikap mental, (2) kepemimpinan, (3) ketatalaksanaan dan (4) keterampilan. Dengan demikian, wirausahawan harus memiliki ciri atau sifat tertentu sehingga dapat disebut wirausahawan. Secara umum, seorang wirausahawan perlu memiliki ciri percaya diri, berorientasi tugas dan hasil, berani mengambil risiko, memiliki jiwa kepemimpinan, orisinalitas dan berorientasi masa depan (Hakim, 1998: 34).

Percaya diri dan keyakinan dijabarkan ke dalam karakter ketidaktergantungan, individualitas dan optimis. Ciri kebutuhan akan berprestasi meliputi karakter berorientasi laba, ketekunan dan ketabahan, tekad dan kerja keras, motivasi yang besar, energik dan inisiatif. Kemampuan mengambil risiko berarti suka pada tantangan. 
Berlaku sebagai pemimpin berarti dapat bergaul dengan orang lain (bawahan), menanggapi saran dan kritik, inovatif, fleksibel, punya banyak sumber, serba bisa dan mengetjahu banyak. Disamping itu, wirausahawan mempunyai pandangan ke depan dan perspektif yang maju.

Karakteristik kewirausahaan menyangkut tiga dimensi, yakni inovasi, pengambilan risiko dan proaktif. Sifat inovatif mengacu pada pengembangan produk, jasa atau proses unik yang meliputi upaya sadar untuk menciptakan tujuan tertentu, memfokuskan perubahan pada potensi sosial ekonomi organisasi berdasarkan pada kreativitas dan intuisi individu. Pengambilan risiko mengacu pada kemauan aktif untuk mengejar peluang. Sedangkan dimensi proaktif mengacu pada sifat assertif dan implementasi teknik pencarian peluang "pasar" yang terus-menerus dan bereksperimen untuk mengubah lingkungannnya

\section{Pengertian Pesantren}

Istilah pondok berasal dari pengertian asrama-asrama para santri yang disebut pondok atau tempat tinggal yang dibuat dari bambu atau berasal dari bahasa Arab fundug, yang berarti hotel atau asrama (Dhofier, 1994: 18). Sedangkan perkataan pesantren berasal dari kata santri (Geertz,1983: 268), dengan awalan pe-dan akhiran-an yang berarti tempat para santri. Sedangkan menurut Nurcholish Madjid terdapat dua pendapat tentang arti kata "santri" tersebut. Pertama, pendapat yang mengatakan beradal dari kata "shastri", yaitu sebuah kata sanskerta yang berarti melek huruf. Kedua, pendapat yang mengatakan bahwa kata tersebut berasal dari bahasa jawa "cantrik" yang berarti seseorang yang selalu mengikuti seorang guru kemanapun guru itu pergi menetap (Madjid, 2006: 21). Nama "pesantren" sering kali dikaitkan dengan kata "santri" yang mirip dengan istilah bahasa india "shastri" yang berarti orang yang mengetahui buku-buku suci agama Hindu atau orang yang ahli tentang kitab suci (Jamhari, 2002: 94).

Selanjutnya kata pondok dan kata pesantren digabung menjadi satu sehingga membentuk pondok pesantren.Pondok pesantren menurut Arifin adalah suatu lembaga pendidikan agama Islam yang 
tumbuh serta diakui masyarakat sekitar dengan sistem asrama (komplek) dimana santri-santri menerima pendidikan agama melalui system pengajian atau madrasah yang sepenuhnya berada di bawah kedaulatan dari leadership seorang atau beberapa orang kiai dengan ciri-ciri khas yang bersifat karismatik serta independent dalam segala hal (Arifin, 1991: 240).

Dari berbagai definisi di atas, penulis menarik kesimpulan bahwa pondok pesantren adalah lembaga pendidikan agama Islam yang dipimpin oleh seorang Kiai yang mempunyai karismatik dan bersifat independent dimana santri disediakan tempat untuk menginap._Terdapat lima elemen dasar yang mutlak ada dalam sebuah tradisi pondok pesantren. Lima elemen tersebut antara lain: pondok sebagai asrama santri, masjid sebagai sentral peribadatan dan pendidikan Islam, santri, pengajaran kitab-kitab klasik dan kiai (Dhofier, 1994: 44).

\section{Nilai-nilai yang dikembangkan di Pesantren}

Menurut Gordon Alport, sebagaimana dikutip Mulyana, nilai adalah keyakinan yang membuat seseorang bertindak atas dasar pilihannya (Mulyana, 2004: 9). Menurut Fraenkel, sebagaimana dikutip Ekosusilo, nilai dapat diartikan sebagai sebuah pikiran (idea) atau konsep mengenai apa yang dianggap penting bagi seseorang dalam kehidupannya (Ekosusilo, 2003: 22). Selain itu, kebenaran sebuah nilai juga tidak menuntut adanya pembuktian empirik, namun lebih terkait dengan penghayatan dan apa yang dikehendaki atau tidak dikehendaki, disenangi atau tidak disenangi oleh seseorang.

Menurut Kuperman, sebagaimana dikutip Mulyana, nilai adalah patokan normatif yang mempengaruhi manusia dalam menentukan pilihannya diantara cara-cara tindakan alternatif (Mulyana, 2004: 9). Menurut Ndraha, nilai bersifat abstrak, karena nilai pasti termuat dalam sesuatu. Sesuatu yang memuat nilai (vehicles) ada empat macam, yaitu: raga, perilaku, sikap dan pendirian dasar (Ndraha, 27-28). Menurut Hans Jonas, yang dikutip Mulyana, nilai adalah sesuatu yang ditunjukkan dengan kata "ya" (Mulyana, 2004: 9-10). Menurut Kuchlohn, sebagaimana dikutip Mulyana, nilai sebagai konsepsi (tersirat atau tersurat, yang sifatnya membedakan 
individu atau ciri-ciri kelompok) dari apa yang diinginkan, yang mempengaruhi pilihan terhadap cara, tujuan antara dan tujuan akhir tindakan (Mulyana, 2004: 9-10). Allport, sebagaimana dikutip Kadarusmadi, menyatakan bahwa nilai itu merupakan kepercayaan yang dijadikan preferensi manusia dalam tindakannya. Manusia menyeleksi atau memilih aktivitas berdasarkan nilai yang dipercayainya (Kadarusmadi, 1996: 55). Jadi nilai merupakan suatu keyakinan atau kepercayaan yang menjadi dasar bagi seseorang atau sekelompok orang untuk memilih tindakannya atau menilai suatu yang bermakna atau tidak bermakna bagi kehidupannya.

Secara vertikal, Alisyahbana, sebagaimana dikutip Ekosusilo, mengklasifikasikan nilai menjadi tiga tingkat, yaitu: 1) tingkat vital, 2) tingkat hati, dan 3) tingkat akal (Ekosusilo, 2003: 25). Nilai tingkat vital berkaitan dengan sesuatu yang dianggap sangat dibutuhkan dalam mempertahankan hidup dan mendapatkan keperluan hidup yang sebagian besar ditentukan oleh insting. Nilai hati muncul karena kesadaran dan pengakuan diri yang didasarkan atas suasana hatinya. Nilai tingkat akal didasarkan pada kesadaran akan perlunya pengorganisasian dan pengawasan terhadap keperluan hidupnya. Nampaknya hal ini juga terjadi di wilayah pondok pesantren. Dalam hal pendidikan kewirausahaan di pondok pesantren itu, aspek yang membedakan dengan lembaga pendidikan secara umum adalah dilandasi dengan internalisasi nilai-nilai kewirausahaan Islami, sehingga jiwa kewirausahaan sangat melekat pada diri seorang santri.

\section{Kewirausahaan Berbasis Kreativitas}

Kreativitas, inovasi dan jiwa kewirausahaan sangat penting dimiliki karena merupakan suatu kemampuan yang sangat berarti dalam proses kehidupan manusia. Makna dan posisi kreativitas dan inovasi itu ibarat sebuah kata tidak ada seorang pun yang tidak memiliki kreativitas. Namun masalahnya adalah bagaimana cara kreativitas dan inovasi tersebut dikembangkan dan diimplementasikan dalam kegiatan riil sesuai dengan wawasan kewirausahaan dalam lembaga pendidikan khususnya di pondok pesantren.

Suatu karya kreatif dan inovatif sebagai hasil kreasi kiai dapat mendorong potensi kerja dan kepuasan pribadi yang tak terhingga 
besarnya. Dengan terobosan kreatif kiai dapat mengoptimalkan kemampuan yang dimiliki untuk merubah tantangan menjadi peluang dan untuk memajukan kiai. Menurut Maslow (Maslow, www.yorku.ca), dalam perwujudan diri manusia, kreativitas dan inovasi merupakan manifestasi dari individu yang memiliki fungsi penuh. Di satu sisi, kreativitas dan inovasi penting dipahami oleh para guru dalam tugas dan tanggang jawabnya sebagai pendidik dan pengajar yang membimbing dan mengantar anak didik ke arah pertumbuhan dan perkembangan prestasinya secara optimal. Di sisi lain, kiai kadang-kadang karena kelemahan rekuritmen tidak memiliki kemampuan tersebut. Padahal, kedudukan kiai menjadi sangat sentral dan penting dalam mengoptimalkan fungsi kreativitas, inovasi dan wawasan kewirausahaan di pesantren yang dipimpinnya.

Selain makna kreativitas, inovatif dan wawasan kewirausahaan perlu pula dipelajari kepentingannya dalam kehidupan di masyarakat dan di tempat kerja. Dengan kata lain, kreativitas yang merupakan pangkal dari langkah inovatif mempunyai nilai penting dalam kehidupan individu. Dalam kaitannya dengan fungsi kreativitas, inovasi dan wawasan kewirausahaan perlu ada komitmen yang tinggi dari kiai dan guru dalam mengembangkan proses pembelajaran di pesantren.

\section{Metode Penelitian}

Penelitian ini adalah termasuk jenis penelitian lapangan (field research) dengan pendekatan kualitatif, yaitu penelitian yang tidak mengadakan penghitungan data secara kuantitatif (Moleong, 1990: 2), dengan paradigma naturalistik atau interpretif. Data dikumpulkan dari latar yang alami (natural setting) sebagai sumber data langsung. Paradigma naturalistik digunakan karena memungkinkan peneliti menemukan pemaknaan (meaning) dari setiap fenomena sehingga diharapkan dapat menemukan local wisdom (kearifan lokal), traditional wisdom (kearifan tradisi), moral value (emik, etik, dan noetik) serta teori-teori dari subjek yang diteliti. Pemaknaan terhadap data secara mendalam dan mampu mengembangkan teori hanya dapat dilakukan apabila diperoleh fakta yang cukup detail dan dapat disinkronkan dengan teori yang sudah ada. 
Rancangan penelitian ini menggunakan rancangan studi kasus, yaitu berusaha mendeskripsikan suatu latar, objek atau peristiwa tertentu secara rinci dan mendalam. Studi kasus adalah penelitian yang bertujuan untuk mempelajari secara intensif mengenai unit sosial tertentu, yang meliputi individu, kelompok, lembaga dan masyarakat (Riyanto, 2001: 24). Penelitian ini akan menghasilkan informasi yang detail yang mungkin tidak bisa didapatkan pada jenis penelitian lain. Lokasi penelitian ini adalah pondok pesantren Sidogiri Pasuruan. Dipilihnya pondok pesantren ini karena pondok pesantren ini melaksanakan aktivitas wirausaha sendiri, bahkan terkenal dengan BMT-nya, kopontren dan air minum santri-nya. Sehingga di dalam pondok pesantren terdapat proses pendidikan kewirausahaan untuk parasantri.

Memperhatikan jenis penelitian tersebut, maka sumber data primer dalam penelitian ini adalah kata-kata dan tindakan pemimpin atau kyai, para ustadz atau guru dan para santri atau siswa Pondok Pesantren Sidogiri Pasuruan. Pemilihan sumber data ini berdasarkan asumsi bahwa merekalah yang terlibat dalam kegiatan proses pendidikan kewirausahaan secara langsung. Adapun sumber data sekunder adalah dokumen atau bahan tertulis atau bahan kepustakaan, yakni buku-buku, artikel, jurnal ilmiah, dan koran yang membahas masalah-masalah yang relevan dengan penelitian ini. Sumber data sekunder lain adalah dokumentasi berupa foto, misalnya fotofoto kegiatan, segala aktifitas maupun sarana dan prasarana yang dapat memberikan gambaran yang nyata pada aspek-aspek yang di teliti, misalnya ruang kelas, ruang halaqah, ruang musyawarah, masjid, ruang tidur, dan lain-lain sebagai tempat dilaksanakannya aktifitas pondok pesantren tersebut.

Data penelitian akan dikumpulkan yang pertama, melalui teknik observasi, yaitu dengan mengunjungi Pondok Pesantren Sidogiri Pasuruan untuk memperhatikan atau mengamati kegiatankegiatan yang diselenggarakan serta mengamati lingkungan sekitarnya. Kedua, dikumpulkan melalui teknik wawancara, yaitu dengan jalan komunikasi langsung dan melakukan tanya jawab kepada kyai, pengurus dan murid untuk memperdalam informasi yang diperoleh dari teknik pengumpulan data yang lainnya. Ketiga, data penelitian akan dikumpulkan melalui dokumentasi, baik dokumen 
resmi Pondok Pesantren Sidogiri Pasuruan seperti aturan-aturan dan sejarah perkembangannya, maupun dokumen dari koran, majalah atau website tentang pondok pesantren tersebut.

Teknik analisis data yang digunakan adalah teknik deskriptif dengan menempuh tiga langkah yang terjadi secara bersamaan menurut Miles dan Huberman yaitu: 1) reduksi data (data reduction), yaitu menggolongkan, mengarahkan, membuang yang tidak perlu dan mengorganisir data; 2) penyajian data (data displays), yaitu: menemukan pola-pola hubungan yang bermakna serta memberikan kemungkinan adanya penarikan kesimpulan; dan 3) penarikan kesimpulan/verifikasi (conclusion drawing/veriffication) (Huberman, 1992: 22).

Pengecekan keabsahan data (trustworthiness) dalam penelitian ini memakai pendapat Lincoln dan Guba bahwa pelaksanaan pengecekan keabsahan data didasarkan pada empat kriteria yaitu derajat kepercayaan (credibility), keteralihan (transferability), kebergantungan (dependability) dankepastian (confirmability) (Guba, 1985: 289-331).

\section{Penanaman Nilai-nilai Kewirausahaan di Pondok Pesantren Sidogiri}

Nilai merupakan dasar sesuatu untuk melakukan kegiatan. Maka, dalam suatu pondok pesantren, dasar untuk melakukan kegiatan di pondok pesantren adalah nilai yang dikembangkan di pondok pesantren tersebut. Demikian juga kegiatan kewirausahaan di pondok pesantren Sidogiri, kegiatannya juga dikembangkan berdasarkan nilai. Demikian ungkapan Ustadz Saifullah Naji, "pondok pesantren ini menanamkan nilai religius, antara lain uswab alhasanah, kedisiplinan, kemandirian, kewirauahaan, nilai ibadah, akhlak dan sebagainya. Hal tersebut dikarenakan supaya santri bisa memahami agama sepenuhnya dan tidak tergantung kepada orang lain" (Naji, Wawancara: 2011).

Naji menambahkan, nilai yang tertanam dalam diri santri adalah nilai keagamaan, yaitu melaksanakan shalat tepat waktu, membiasakan membaca al-Qur'an, nilai pergaulan, misalnya sopan santun ketika bergaul dengan siapapun dan nilai etika, baik dalam 
berpakaian, kesopanan dan sebagainya (Naji, Wawancara: 2011).

Berpijak dari nilai-nilai yang ditanamkan di ponpes Sidogiri yang dikemukakan oleh Ustadz Saifullah Naji, nampaknya yang digunakan sebagai dasar pendidikan dan kegiatan kewirausahaan di pondok pesantren adalah nilai kewirausahaan dan nilai ibadah yang semuanya terpusat pada core value yaitu keimanan, berupaprinsip amanab dan siddiq. Ibadah merupakan bahasa Indonesia yang berasal dari bahasa Arab, yaitu dari masdar 'abada yang berarti penyembahan. Sedangkan secara istilah berarti khidmat kepada Tuhan, taat mengerjakan perintahNya dan menjauhi laranganNya (Zain, 524). Jadi ibadah adalah ketaatan manusia kepada Tuhan yang diimplementasikan dalam kegiatan sehari-hari misalnya sholat, puasa, zakat, dan lain sebagainya.

Nilai ibadah perlu ditanamkan kepada diri seorang santri, agar santri menyadari pentingnya beribadah kepada Allah, bahkan penanaman nilai ibadah tersebut hendaknya dilakukan ketika anak masih kecil dan berumur 7 tahun serta dalam setiap kegiatan hendaknya juga diniatkan sebagai ibadah, yaitu ketika terdapat perintah kepada anak untuk menjalankan shalat. Dalam ayat yang menyatakan tentang shalat misalnya redaksi ayat tersebut memakai lafadh aqim bukan if'al. Hal itu menunjukkan bahwa perintah mendirikan shalat mempunyai nilai-nilai edukatif yang sangat mendalam, karena shalat itu tidak hanya dikerjakan sekali atau dua kali saja, tetapi seumur hidup selama hayat masih dikandung badan (Mufarakah, 2008: 8). Penggunaan kata aqim tersebut juga menunjukkan bahwa shalat tidak hanya dilakukan, tetapi nilai shalat wajib diimplementasikan dalam kehidupan sehari-hari, misalnya kedisiplinan, ketaatan kepada Tuhannya, kedisiplinan dalam berwirausaha, kejujuran, berusaha tanpa kenal menyerah dan sebagainya. Menurut Wahbah Zuhaily, penegakan nilai-nilai shalat dalam kehidupan merupakan manifestasi dari ketaatan kepada Allah. Shalat merupakan komunikasi hamba dan khaliknya, semakin kuat komunikasi tersebut, semakin kukuh keimanannnya (Al-Zuhaily, 2005:163).

Sebagai seorang pendidik, kiai tidak boleh lepas dari tanggung jawab begitu saja, namun sebagai seorang pendidik hendaknya senantiasa mengawasi santrinya dalam melakukan ibadah, karena ibadah tidak hanya ibadah kepada Allah atau ibadah 
mabdlah saja, namun juga mencakup ibadah terhadap sesama atau ghairu mahdlah. Ibadah di sini tidak hanya terbatas pada menunaikan shalat, puasa,mengeluarkan zakat dan beribadah haji serta mengucapkan syahadat tauhid dan syahadat Rasul, tetapi juga mencakup segala amal, perasaan manusia, selama manusia itu dihadapkan karena Allah SWT. Ibadah adalah jalan hidup yang mencakup seluruh aspek kehidupan serta segala yang dilakukan manusia dalam mengabdikan diri kepada Allah SWT. Tanpa ibadah, maka manusia tidak dapat dikatakan sebagai manusia secara utuh, akan tetapi lebih identik dengan makhluk yang derajatnya setara dengan binatang.

Sehingga jika nilai ibadah ini digunakan sebagai juklak pendidikan kewirausahaan, maka hal ini akan berdampak pada segala kegiatan wirausaha yang ada di pondok pesantren diniatkan dan dilakukan untuk beribadah kepada Allah swt. Di sisi lain, hal ini juga akan memperkuat keimanan seseorang dalam melakukan sesuatu. Artinya segala sesuatu yang dilakukan oleh santri, akan senantiasa diliputi oleh nilai keimanan. Dengan kata lain, santri dalam menjalankan usaha senantiasa merasa bahwa ia diawasi oleh Allah Swt.

\section{Proses Pendidikan Kewirausahaan di Pondok Pesantren Sidogiri}

Proses pendidikan kewirausahaan di pondok pesantren Sidogiri dimulai dengan menjalankan sumber-sumber ekonomi pondok pesantren Sidogiri. Dengan modal nilai kemandirian dan pengembangan life skill, santri diharapkan bisa mengelola aspek-aspek sumber ekonomi yang ada pada pondok pesantren tersebut. Nampaknya hal itu tidak hanya ditujukan kepada santri saja, melainkan juga alumni. Menurut Saifullah Naji, dalam hal khidmah di bidang ekonomi kami memiliki berbagai bidang penguatan ekonomi, seperti Kopontren yang mengurusi masalah usaha retail dan air minum santri, BMT, pengelolaan limbah, balai pelatihan untuk penguatan ekonomi dan entrepreneurship, dan lain sebagainya. Semua pengelolanya adalah santri alumni aliyah ponpes Sidogiri (Abdullah, Wawancara: 2011). Jadi usaha-usaha dan badan usaha ekonomi yang ada di pondok pesantren Sidogiri digunakan untuk menanam- 
kan jiwa kewirausahaan kepada santri.

Pemberian bekal itu penting dikarenakan ketika santri terjun ke masyarakat, maka santri akan mempunyai bekal berupa kemampuan untuk berwirausaha atau mendirikan usaha kerja sendiri dan tidak bergantung kepada usaha yang lain. Hal yang sama juga diungkapkan oleh Samsul Huda sebagai berikut:

Kita memprioritaskan anggota BMT adalah alumni santri Sidogiri. Taruhlah BMT kita ada 140 cabang. Setiap cabang ada 7 pegawai. Itu sudah 980 karyawan. Padahal alumni kita rata-rata tiap tahun 500-an alumni. Ini masih sangat mencukupi. Belum lagi yang kopontren yang ada di berbagai cabang, dan ke depan kami akan terus mengembangkan cabang-cabang yang ada di daerah. Sehingga kami sekarang ini sedang membangun balai pelatihan milik sendiri yang sekarang masih dalam proses pembangunan. Sekarang ini di bidang ekonomi itu ada 8 orang menangani pemberdayaan ekonomi. Mengenai perekrutan tenaga pekerja, pada dasarnya kami tetap melihat prestasi akademik santri dulu. Namun perekrutan di sini ini modelnya unik. Kadang kami tidak tahu kalau kami mau direkrut untuk bergabung dalam pengurus. Hal ini biasanya penunjukan langsung dari anggota keluarga/kiai. Selain itu juga ada pertimbangan lain selain prestasi akademik.

Selain itu Muhbir menambahkan tentang program pendidikan kewirausahaan sebagai berikut:

Di ponpes ini juga seringkali diadakan pelatihan kepemimpinan misalnya, dari situ pengelola bisa melihat santri mana yang memiliki potensi. Jadi kami belajar sambil jalan. Kami juga mendapatkan pelatihan langsung wirausaha, yang diprogramkan setiap tahun. Materinya sesuai usulan dan kebutuhan kita, dan nanti praktek langsung. Bisa pada desain percetakan, sablon, peternakan, perikanan, pertanian, pengelolaan koperasi, dan lain-lain (Muhbir, Wawancara: 2011).

Ustadz Saifulloh Naji juga menjelaskan:

Kami menggunakan SDM dari alumni santri yang sudah tamat Aliyah. Walau mereka tidak sekolah formal, tanpa ijazah S1 namun kami memegang prinsip bahwa masalah teknis bisa dipelajari 1, 2 minggu maksimal 1 bulan, selanjutnya sudah bisa berjalan lancar. Masalah perekrutan karyawan kami hanya memegang dua prinsip utama yaitu sidiq (benar/jujur) dan amanah (dapat dipercaya). Kami yakin kalaulah seseorang itu sudah memiliki dua sifat tersebut maka 
selanjutnya tinggal menggodok fatonah (kecerdasan) dan selanjutnya tableqh (menyampaikan). Dua hal yang terakhir ini bisa didapat by process (Naji, Wawancara 2011).

Hal ini juga didukung observasi yang peneliti lakukan: Beginilah suasana kantor pusat kegiatan ekonomi ponpes Sidogiri. (Kantornya sangat bagus, bersih dan rapi persis seperti kantor bankbank konvensional sudah menggunakan layanan on line dengan sekat-sekat ruang yang sudah tertata jelas, menunjukkan bahwa manajemennya berjalan) (Observasi, 2011).

Mengenai omset dan seputar BMT tersebut, Ustadz Saifulloh juga menjelaskan:

Omsetnya per-September kemarin mencapai angka 1 Trilyun. diawali dari 140 juta pada tahun 2000. Sebetulnya awal mula BMT dimulai dari keprihatinan pondok terhadap para masyarakat yang ada di sekeliling pondok yang memiliki usaha kecil (berjualan di sekitar ponpes) yang berhutang kepada rentenir untuk memulai usahanya. Modal dari rentenir, sementara di makan oleh para santri menimbulkan inisiatif dari pengelola untuk membantu mengentaskan mereka dari para rentenir. Akhirnya muncullah BMT Sidogiri. Awalnya kami membantu memberi modal dengan tanpa laba. Setelah nasabah bisa mandiri akhirnya demi pengembangan BMT pada tahun-tahun seterusnya kami mengelolanya. Sampai dengan saat ini sudah ada 138 cabang BMT di seluruh Indonesia. Nanti jam 14.00 ini ada rapat pertemuan BMT sidogiri se-Ind di hotel Semeru Batu (Naji, Wawancara, 2011).

Bahkan BMT terrsebut dijadikan rujukan oleh BMT-BMT yang lain. Ustadz Saifulloh menjelaskan:

Memang BMT ini menjadi rujukan yang lain. Kemarin ada utusan dari PBNU untuk mengadakan pelatihan langsung di sini selama 2 bulan untuk mengkaji tentang konsep Ekonomi Syari'ah yang dikembangkan oleh UGT ini. Tempatnya ya di sini ini. (Gedung UGT terdiri dari tiga lantai, dengan lantai dasar untuk transaksi, ltu dua untuk ruang perkantoran, dan lantai tiga untuk gedung pertemuan) (Naji, Wawancara: 2011).

Memang pada dasarnya dan awal niat dari BMT ini adalah berjuang. Tapi apabila perjuangan tersebut disertai dengan keikhlasan, maka akan membuahkan hasil juga. Ustadz Saifulloh 
menjelaskan hal ini sebagai berikut:

Sebetulnya niat kami adalah berjuang. Ada yang berjuang lewat pendidikan, berjuang lewat pengajian (dakwah), dan urusan ekonomi ini kami juga berjuang. Di dunia ini juga butuh hidup. Keluarga bisa menyekolahkan anaknya di pondok juga butuh biaya. Kalaulah kami membantu memberikan modal usaha, semuanya supaya bisa survive di dunia untuk berjuang kembali menjalankan ibadah dan menegakkan agama. Sungguh sangat tragis kalau menengok nasib para ustadz-ustadz madrasah diniyah kita. Mereka hanya digaji sangat tidak seberapa dengan mengharap keikhlasan saja. Ya...ikhlas yang bagaimana kalau satu bulan hanya digaji 50 ribu..., Sebetulnya inilah yang menjadi keprihatinan kami. Kami ingin mengangkat kembali madrasah diniyah. ... untuk karyawan kami yang baru masuk saja kami memberi UMR tertinggi di Jawa Timur, yaitu standar kami Gresik. Karyawan baru kami beri gaji Rp. 1.050.000,-(Wawancara dengan Sholeh, 2011).

Dari paparan tersebut di atas menunjukkan bahwa niat pertama kali organisasi ekonomi di pondok pesantren Sidogiri adalah berjuang dan berdakwah. Hal inilah yang justru akhirnya mampu digunakan untuk melakukan pendidikan kewirausahaan dengan sendirinya. Pondok pesantren Salafiyah Sidogiri dalam mendidik jiwa kewirausahaan para santrinya yang memegang pada dua hal, yaitu siddiq dan amanah, pada dasarnya merupakan dua modal terbesar dan terpenting yang dibangun dalam karakter santri. Jika dua hal ini sudah terbangun, maka bangunan apapun yang ada diatasnya akan terbentuk dengan baik dan membawa manfaat.

Ponpes Sidogiri lebih banyak membentuk karakter dari hati, sehingga diistilahkan dengan mendidik dengan hati. Dengan siddiq dan amanah, ponpes mengutamakan nilai-nilai tawadlu. Artinya ponpes mendidik para santrinya untuk memiliki jiwa wirausaha berangkat dari spiritual dan emosionalnya dahulu. Sedang dari sisi intelektualnya itu kalau hati sudah terbentuk. Kalau di luar ponpes hal demikian sebaliknya, dari intelektual dulu baru ke hati. Sebenarnya kedua-duanya itu bagus. Tetapi dalam prinsip ponpes Sidogiri, kalau intelektual dulu baru ke hati dan itu tidak kesampaian maka ini yang berakhir menjadi tidak bagus. Kedua fenomena ini sama-sama bagus, tetapi Sidogiri lebih memilih cara yang pertama itu. 
Selain itu budaya sami'na wa ato'na mendukung proses pendidikan kewirausahaan santri. Dua hal ini, akal dan hati kalau bisa digabung menjadi malaikat. Hati dengan akal kalau bisa digabung menjadi malaikat. Kritis saja tidak beretika tidak bagus, beretika saja tanpa kritis juga akan vakum. Inilah yang dijadikan bangunan dasar yang dikokohkan di ponpes Sidogiri dalam rangka memberikan pendidikan kewirausahaan pada santrinya. Setelah santri memiliki bangunan karakter yang kuat, maka selanjutnya kreativitas kiai dalam pengembangan ekomomi dibutuhkan untuk menaungi para santrinya untuk implementasi langsung di lapangan.

Kreativitas kiai, dalam hal ini pondok pesantren Sidogiri, sangat bagus untuk ditiru, karena ponpes Sidogiri mendorong santrinya untuk berkhidmah di berbagai bidang ekonomi, seperti Kopontren yang mengurusi masalah usaha retail dan air minum 'Santri', BMT berkonsep ekonomi syari'ah, pengelolaan limbah, dan usaha percetakan. Sedang bagi santri yang masih dalam tahap belajar wirausaha disediakan pula balai pelatihan untuk penguatan ekonomi dan entrepreneurship, dan lain sebagainya. Pendidikan kewirausahaan yang by action tersebut merupakan pengejawantahan dari kreativitas kiai. Hal ini berarti bahwa kiai menyadari akan adanya sumber daya internal di pondok pesantren yang perlu untuk dididik dan dibina secara lebih lanjut. Santri dipandang sebagai aset pesantren, artinya santri bukan sebagai objek pungutan biaya penyelenggaraan pendidikan semata tetapi sebagai sumber daya yang dapat bermanfaat baik secara ekonomis maupun nonekonomis. Untuk mengawali kegiatan santri sebagai aset diperlukan data santri termasuk hobi serta bakat dan minatnya.

Sebagai ilustrasi apabila santri memiliki siswa berjumlah 500 orang, persantri memiliki rata-rata 4 orang dalam satu keluarga (ayah, ibu, adik/kakak dan siswa itu sendiri) maka ada 2000 orang yang mempunyai hubungan dengan sekolah. Dari 2000 orang tersebut dapat dilakukan penelitian atas suatu obyek sosial yang ada di masyarakat bekerja sama dengan lembaga terkait yang membutuhkan penyebaran instrumen atau kajian dari penelitian tersebut.

Ustadz dan pengurus sebagai aset pesantren. Paradigma lama yang memandang ustadz dan pengurus pesantren sebagai beban 
biaya penyelenggaraan pendidikan di pesantren sebaiknya mulai diubah, karena di antara para ustadz banyak yang memiliki keahlian dan bakat tertentu yang dapat "dijual" sekiranya bakat terpendam tersebut dikembangkan melalui wadah yang sesuai. Apabila seorang kiai bisa menempatkan dirinya dan kreatif juga berjiwa wirausaha, maka ia bisa mengelola potensi santri dengan menanamkan jiwa kewirausahaan terlebih dahulu lalu dilanjutkan dengan melatih santri untuk melakukan suatu kegiatan ekonomi yang berarti, mengelola lembaga ekonomi yang manfaatnya untuk santri. Di samping itu, akan menguntungkan pondok pesantren yang mempunyai lembaga tersebut. Walaupun sebenarnya keuntungan pondok pesantren tersebut tidak selalu menjadi prioritas utama, karena yang ditanamkan pertama pada lembaga wirausaha pondok pesantren adalah untuk beribadah semata-mata mengharap ridho Allah.

\section{Kesimpulan}

Nilai-nilai kewirausahaan yang diinternalisasikan di pondok pesantren Sidogiri adalah nilai kewirausahaan yang berbasis ibadah, dimana segala kegiatan ekonomi yang dilakukan diniatkan untuk beribadah kepada Allah SWT. Nilai ibadah tersebut berintikan pada keimanan. Semakin tinggi keimanan seseorang, maka semakin baik pengelolaannya terhadap lembaga ekonomi dan semakin tebal jiwa kewirausahaannya.

Proses pendidikan kewirausahaan yang dilaksanakan di pondok pesantren Sidogiri adalah santri dilatih untuk mengelola lembaga ekonomi yang ada di pondok pesantren Sidogiri, di bawah pantauan dari kiai dan pengurus pondok pesantren. Sedangkan keuntungan pondok pesantren tersebut tidak selalu menjadi prioritas utama, karena yang ditanamkan pertama pada lembaga wirausaha pondok pesantren adalah semua dikerjakan untuk beribadah dan semata-mata mengharap ridho Allah, sehingga santri selain memiliki bekal ilmu agama kuat juga memiliki bekal jiwa wirausaha untuk kehidupan dunia yang kokoh. 


\section{DaftarPustaka}

Al-Qardhawi, Yusuf. 2000. Tuntunan Membangun Masjid.ter. Abdul Hayyie al-Kattani, ed. Darmadi, Jakarta: Gema Insani Press. al-Zuhaily, Wahbah. 2005. Tafsir al-Munir. juz 11, Beirut: Dar alFikr.

Arifin, Imron 1993. Kepemimpinan Kiai: Kasus Pondok Pesantren Tebuireng, Malang: Kalimasahada Press

Arifin, M., 1991. Kapita Selekta Pendidikan (Islam dan Umum), Jakarta: Bumi Aksara

Azra, Azyumardi, 1985."Surau di Tengah Krisis: Pesantren dan Perspektif Masyarakat", dalam Rahardjo (ed.), Pergulatan Dunia Pesantren Membangun dari Bawah, Jakarta: LP3ES

Badudu, J.S, 1996. Sutan Muhammad Zain, Kamus Umum Bahasa Indonesia, Jakarta: Pustaka Sinar Harapan

Depdiknas. 2007. Kewirausahaan Sekolah Berbasis Kreativitas dan Inovasi, Jakarta: Direktorat Tenaga Kependidikan Departemen Pendidikan Nasional

Dhofier, Zamakhsari, 1994. Tradisi Pesantren; Studi pandangan Hidup Kyai, jakarta; LP3ES

Ekosusilo, Madyo. 2003. Hasil Penelitian Kualitatif Sekolab Unggul Berbasis Nilai: Studi Multi Kasus di SMAN 1, SMA Regina Pacis, dan SMA al-Islam 01 Surakarta, Sukoharjo: UNIVET Bantara Press

Gazalba, Sidi. 1989. Mesjid Pusat Ibadah dan Kebudayaan Islam, Jakarta: Pustaka Al-Husna, Cetakan V

Geertz, Clifford. 1983. Abangan Santri, Priyayi Dalam Masyarakat Jawa, terj. Aswab Mahasin, Jakarta: Dunia Pustaka Jaya

Haidar, M. Ali. 1994. Nabdlatul Ulama dan Islam di Indonesia Pendekatan Fiqh dalam Politik, Jakarta: PT. Gramedia Pustaka Utama

Hakim, Rusman. 1998. Dengan Berwiraswasta Menepis Krisis: Konsep Membangun Masyarakat Entrepreneur Indonesia, Jakarta: Alex Media Komputindo

Hariadi, Farid Ma'ruf. "Arah Baru Pengelolaan Pondok Pesantren", dalam Episteme Jurnal Pengembangan Ilmu Keislaman, vol. 3, Juni 2008. 
Jabali, Fuad, Jamhari. 2002. IAIN dan Modernisasi Islam di Indonesia, Jakarta : Logos Wacana Ilmu

Kadarusmadi. 1996. Upaya Orang Tua dalam Menata Situasi Pendidikan dalam Keluarga, Disertasi tidak dipublikasikan, Bandung: PPs IKIP Bandung

Katsoff, Louis O. 1989. Elements of Philosophy, terj. Soejono Soemargono, Yogyakarta: Tiara Wacana

Langgulung, Hasan. 1988. Pendidikan Islam Menghadapi Abad ke21, Jakarta: Pustaka Al-Husna

Latif, Abdul. 2006. Pendidikan Berbasis Nilai Kemasyarakatan, Bandung: Refika Aditama

Lincoln, YS., Egon G. Guba. 1985. Naturalistic Inquiry, Beverly Hill, Caifornia: Sage Publications

M.B, Miles \& Huberman A.Mikel. 1992. Qualitative Data Analisis, Beverly Hills: SAGE Publication, Inc

Madjid, Nurcholis. 2006. Bilik-Bilik Pesantren, Jakarta: Paramadina Maslow, A.B. A Theory of Human Motivation, dalam Christopher D. Green (http://www.yorku.ca/dept/psych/classics/ author.htm)

Mestoko, Sumarso et.al. 1986. Pendidikan di Indonesia dari aman ke-Jaman, Jakarta: Balai Pustaka

Moleong, Lexy J. 1990. Metode Penelitian Kualitatif, Bandung: Remaja Rosda Karya

Mufarakah, Anisatu. "Pendidikan Dalam Perspektif Luqman alHakim: Kajian Atas QS: Luqman ayat 12-19”, dalam Ta'allum Jurnal Pendidikan Islam Vol.18.No.O1, juni 2008

Mulyana, Rohmat. 2004. Mengartikulasikan Pendidikan Nilai, Bandung: Alfabeta

Munandar, Aris. 2006. Pengembangan Kewirausahaan Sekolah, Jakarta: Direktorat Tenaga Kependidikan Departemen Pendidikan Nasional

Noor, Mahpuddin. 2006. Potret Dunia Pesantren: Lintasan Sejarah, Perubahan dan Perkembangan Pondok Pesantren, Bandung: Humaniora

Riyanto, Yatim. 2001. Metodologi Penelitian Pendidikan. Surabaya: SIC 
Rosyadi, Khoiron. 2004. Pendidikan Profetik, Cet.1, Yogyakarta: Pustaka Pelajar

Saridjo, Marwan et.al. 1982. Sejarah Pondok Pesantren di Indonesia. Jakarta: Dharma Bhakti

Sofia, Aya, et.al. 1985/1986, Pedoman Penyelenggaraan Pusat Informasi Pesantren. ProyekPembinaan dan Bantuan Kepada Pondok Pesantren di Jakarta Departemen Agama RI.

Sunyoto. 1995. "Pondok Pesantren Dalam Alam Pendidikan Nasional", dalam M. Dawam Rahardjo (ed)., Pesantren Pembaharuan, ttp: LP3ES

Supeno. Wahyudin. 1984. Perpustakaan Masjid, Pembinaan dan Pengembangannya,ed. Abdul Hamid, Bandung: Remaja Rosdakarya.

Tim Dosen Administrasi Pendidikan UPI. 2009. Manajemen Pendidikan, Bandung: Alfabeta

Tolkhah, Imam, Barizi. 2004. Membuka Jendela PendidikanMengurai Akar Tradisi, Jakarta: PT. Raja Grafindo Persada

Wahid, Abdurrahman. 1995. "Pesantren Sebagai Subkultur", dalam M. Dawam Rahardjo (ed.). Pesantren dan Pembaharuan. ttp: LP3ES

Yasmadi. 2002. Modernisasi Pesantren: Kritik Nurcholis Madjid terhadap Pendidikan Tradisional. Jakarta: Ciputat Press Zuhairini. 1992. Sejarah Pendidikan Islam. Jakarta: Bumi Aksara 